\title{
Factors That Affect Saudi Population Preferences Toward Their Dentist
}

\author{
Suliman Alsaeed ${ }^{1-3}$ \\ Norah Alghurairi ${ }^{4}$ \\ Lamia Almutairi $\mathbb{1 D}^{4}$ \\ Afrah Alossimi ${ }^{4}$ \\ Afnan Bin Fadhl ${ }^{4}$ \\ Sadeem Abahussain ${ }^{4}$ \\ 'Preventive Dental Sciences Department, \\ College of Dentistry, King Saud bin \\ Abdulaziz University for Health Sciences, \\ Riyadh, Saudi Arabia; ${ }^{2}$ King Abdullah \\ International Medical Research Center, \\ Riyadh, Saudi Arabia; ${ }^{3}$ Ministry of the \\ National Guard - Health Affairs, Riyadh, \\ Saudi Arabia; ${ }^{4}$ College of Dentistry, King \\ Saud bin Abdulaziz University for Health \\ Sciences, Riyadh, Saudi Arabia
}

Correspondence: Suliman Alsaeed College of Dentistry, King Saud bin Abdulaziz University for Health Sciences, Riyadh, Saudi Arabia

Email saeedsu@ksau-hs.edu.sa; suliman.as@hotmail.com
Objective: To explore the preference of Saudi population when selecting their dentist.

Design: Cross-sectional observational study.

Methods: An online questionnaire was distributed in Arabic language. The inclusion criteria were Saudi participants, aged 18 years or above. The questionnaire was divided into four sections that included participants' demographic data, preferred criteria on dentists and dental office design, and table for the importance of each of the factors studied.

Results: A sample size of 5317 participants completed the questionnaire with a mean age of $30.5 \pm 11.6$ years old, $57 \%$ were females. Most of the participants had no preference on their dentist's nationality $(63 \%)$ or gender $(44 \%)$. There was a preference for dentists who are consultants $(38 \%)$, well known (83\%), and has an explanatory-style consultation $(78 \%)$. Participants preferred scrub and lab coat attires for their male (41\%) and female $(38 \%)$ dentists. Less than half of the participants (44.8\%) preferred the dentist to have a social media account. Of all social media platforms, Twitter was the most preferred one (37\%). White clinic color was more preferable than other colors (56\%). Of all the factors studied, dentist's reputation, clinical rank and cost of treatment were considered very important for most of the participants when selecting their dentist.

Conclusion: Overall, Saudi participants have specific preferences on their dentists and dental office design. Dentists might consider these factors to improve their dental practice and their patients' experience.

Keywords: patients' preferences, dentistry, private practice, Saudi population, marketing

\section{Introduction}

The process of choosing a dentist for a dental treatment is influenced by multiple factors and differs between different populations. ${ }^{1-8}$ Hence, it is challenging for dentists to attract patients and deliver the required effective dental treatment without prior knowledge of the factors that affect patients' preference. To solve this, an evaluation tool could be implemented to study the contributing factors in patients' preferences of their dentists, such as age, sex, and educational level, as this will help dentists in forming a better understanding of the patients' choices.

A British study conducted on a sample of 257 participants has shown that patients preferred younger dentists to older ones and locally trained dentists over internationally trained. ${ }^{2}$ In terms of dentists' gender, a study conducted in Riyadh, Saudi Arabia on a sample of 445 participants concluded that male participants had a preference for male dentist, while female participants had no specific preference on dentists' gender. ${ }^{3}$ In regard to dentists' attire, multiple studies showed a general preference for scrub and white coat. ${ }^{4-8}$ Moreover, a study conducted in 2015 on 
a sample of 445 participants investigated the preference of patients on dentists' nationality. Most participants $(66 \%)$ did not have any preference for the nationality of the dentist, while 19\% preferred Saudi and 14\% preferred non-Saudi dentist. ${ }^{3}$

However, no studies in the Kingdom of Saudi Arabia have examined whether the educational level, income level or insurance status of the patients contribute to their dentists' preference. Moreover, previous studies in Saudi Arabia were limited by small sample size, and focused on few variables. The aim of this study was to compensate for the limitations of previous studies by studying multiple factors, on a large sample size across Saudi Arabia, that could affect the Saudi population's preferences in choosing their dentists, in terms of sex, nationality, professional degree, social media page, reputation, dentist's communication styles (listener or explanatory), attire and dental office-related factors, such as clinic design and colors, and to study how the patient's demographic data affect their opinions.

\section{Methodology}

Ethical approval of the study was obtained from the research ethics Committee of King Abdullah International Medical Research Centre (KAIMRC), Ministry of National Guard, Saudi Arabia (IRB $\backslash S P 20 \backslash 322 \backslash R$ ). The study was conducted in accordance with the Declaration of Helsinki, with informed consent gathered from all participants.

This cross-sectional observational study was carried out in September 2020 in Saudi Arabia. The targeted sample was Saudi population aged 18 years and above. The sample size was calculated based on a confidence interval of $95 \%$ and estimated population response distribution of $50 \%$, which yielded a total of 385 subjects required from each of the five main regions of the Kingdom of Saudi Arabia (KSA), which equals a total of 1925 subjects. $^{9,10}$ A stratified sampling technique was used to obtain the sample in the five main regions of KSA. The questionnaire was developed by the research team and was written in Arabic language.

\section{Validity}

A pilot study of 25 participants was conducted for validation purposes. Their comments were recorded and reviewed to improve the clarity of the questionnaire.

The questionnaire was divided into four main sections (demographic data of the participants, preferred criteria on dentists and dental offices, and table for the importance of each of the factors studied; Appendix). An electronic version of the questionnaire (Google Forms ${ }^{\circledR}$ ) was used and distributed throughout hospital waiting areas and social media platforms (Twitter, Instagram, and WhatsApp). Collected data were entered in Microsoft Excel. JMP ${ }^{\circledR}$ was used for statistical analysis. Statistical significance was set to 0.05 or less.

Chi-square test and Fisher's exact test were used to compare the proportions between categorical variables.

\section{Results \\ Demographic Data}

A total of 5317 Saudis responded to the questionnaire with a mean age of $30.5 \pm 11.6$ years old, $57 \%$ were females. The majority of the participants $(43 \%)$ were from the central region, $66 \%$ had bachelor's degrees, and 57\% had income less than 8999 SR. The majority of the participants (76\%) had no insurance, and $80 \%$ stated that most of their dental visits were in private clinics (see Table 1) shows the detailed presentation of participants' demographic data.

\section{Dentist-Related Factors Nationality of the Dentist}

The majority of the participants $(63 \%)$ had no preference on the nationality of the dentist, while $30 \%$ preferred Saudi dentists, and only $7 \%$ preferred non-Saudi (see Table 2). There were no significant differences between the different demographic types of the participants in regard to their preference of dentist's nationality. Most of the participants $(60 \%)$ rated this variable as not important when choosing their dentists (see Table 3).

\section{Sex of the Dentist}

The preference on the dentists' gender differed between different specialties. For general practitioners (GPs), 44\% of the participants did not matter to them the gender of GP, while $36 \%$ for pediatric dentistry (PDs); $42 \%$ of the participants did not matter to them the gender of the PD, while $23 \%$ preferred male PD and $34 \%$ preferred female PD (see Table 2).

There was no effect of most of the demographic data on the gender preference of GPs or PDs, except the age of the participants. The majority of the participants, aged 32 years old and older, preferred male gender for their GPs, but female gender for PDs (see Table 4).

In regard to the preferred gender of oral and maxillofacial surgeon (OMFS), there was more preference for male OMFS (47\%) over females $(12 \%)$, while $41 \%$ had no specific preference (see Table 2). There was significantly $(p<0.0001)$ 
Table I Demographic Data of the Participants $(N=5317)$

\begin{tabular}{|c|c|}
\hline Variable & $\mathbf{N}(\%)$ \\
\hline \multicolumn{2}{|l|}{ Sex } \\
\hline Male & 2298 (43\%) \\
\hline Female & 3019 (57\%) \\
\hline Age & $N=5315$ \\
\hline$<21$ years old & $1339(25 \%)$ \\
\hline $22-25$ years old & $1242(23 \%)$ \\
\hline $26-31$ years old & $808(15 \%)$ \\
\hline $32-41$ years old & $944(18 \%)$ \\
\hline$>42$ years old & $982(18 \%)$ \\
\hline \multicolumn{2}{|l|}{ Region } \\
\hline Northern region & $875(16 \%)$ \\
\hline Western region & $826(16 \%)$ \\
\hline Central region & 2264 (43\%) \\
\hline Eastern region & 734 (14\%) \\
\hline Southern region & $618(12 \%)$ \\
\hline Educational Level & $N=5316$ \\
\hline High School & 1279 (24\%) \\
\hline Bachelor's degree & $3491(66 \%)$ \\
\hline Master's degree & $236(4 \%)$ \\
\hline PhD's degree & 74 (1.3\%) \\
\hline Less than high school & $32(1 \%)$ \\
\hline Diploma & 194 (4\%) \\
\hline Academic training institution & $10(0.1 \%)$ \\
\hline \multicolumn{2}{|l|}{ Income } \\
\hline$<8999$ SR & 3750 (57\%) \\
\hline $9000-14,900$ SR & 1404 (26\%) \\
\hline$>15,000 \mathrm{SR}$ & $856(16 \%)$ \\
\hline \multicolumn{2}{|l|}{ Clinic type } \\
\hline Governmental & $1044(20 \%)$ \\
\hline Private & $4273(80 \%)$ \\
\hline Insurance & $N=4237$ \\
\hline Yes, I do have & $1018(24 \%)$ \\
\hline No, I do not have & 3255 (76\%) \\
\hline Insurance price & $N=1018$ \\
\hline$<2000 \mathrm{sr}$ & $292(29 \%)$ \\
\hline $2000-4000 \mathrm{sr}$ & 391 (38\%) \\
\hline $4000-6000 \mathrm{sr}$ & 170 (I7\%) \\
\hline$>6000 \mathrm{sr}$ & 165 (16\%) \\
\hline
\end{tabular}

more participants of the group who aged 32 years old or older (57\%) who preferred male OMFS. See Table 4.

However, most of the participants (52\%) rated dentists' gender as not important when choosing their dentists (see Table 3).

\section{Age of the Dentist}

The majority of the participants $(64 \%)$ did not matter to them the age of the dentist, while $30 \%$ preferred older
Table 2 Descriptive Analysis on Participants' Preferences on Their Dentists

\begin{tabular}{|c|c|}
\hline Variable & $\mathbf{N}(\%)$ \\
\hline $\begin{array}{l}\text { Dentist Nationality } \\
\text { Saudi } \\
\text { Non-Saudi } \\
\text { Does not matter }\end{array}$ & $\begin{array}{l}1598(30 \%) \\
388(7 \%) \\
3331(63 \%)\end{array}$ \\
\hline $\begin{array}{l}\text { Specialty/Sex (general) } \\
\text { Male } \\
\text { Female } \\
\text { Does not matter }\end{array}$ & $\begin{array}{l}1888(36 \%) \\
1078(20 \%) \\
235 \mid(44 \%)\end{array}$ \\
\hline $\begin{array}{l}\text { Specialty/Sex (pedodontist) } \\
\text { Male } \\
\text { Female } \\
\text { Does not matter }\end{array}$ & $\begin{array}{l}1247(23 \%) \\
1813(34 \%) \\
2257(42 \%)\end{array}$ \\
\hline $\begin{array}{l}\text { Specialty/Sex (surgery) } \\
\text { Male } \\
\text { Female } \\
\text { Does not matter }\end{array}$ & $\begin{array}{l}2508(47 \%) \\
649(12 \%) \\
2160(41 \%)\end{array}$ \\
\hline $\begin{array}{l}\text { Dentist age } \\
\text { Young } \\
\text { Old } \\
\text { Does not matter }\end{array}$ & $\begin{array}{l}327(6 \%) \\
1587(30 \%) \\
3403(64 \%)\end{array}$ \\
\hline $\begin{array}{l}\text { Dentist rank } \\
\text { General dentist } \\
\text { Specialist } \\
\text { Consultant } \\
\text { Does not matter }\end{array}$ & $\begin{array}{l}287(5 \%) \\
1722(32 \%) \\
2043(38 \%) \\
1265(24 \%)\end{array}$ \\
\hline $\begin{array}{l}\text { Dentist reputation } \\
\text { Well known } \\
\text { Not known } \\
\text { Does not matter }\end{array}$ & $\begin{array}{l}4428(83 \%) \\
21(0.4 \%) \\
868(16 \%)\end{array}$ \\
\hline $\begin{array}{l}\text { Dentist characteristic } \\
\text { Listener } \\
\text { Explanatory }\end{array}$ & $\begin{array}{l}1163 \text { (22\%) } \\
4154(78 \%)\end{array}$ \\
\hline $\begin{array}{l}\text { Social media } \\
\text { Yes } \\
\text { No }\end{array}$ & $\begin{array}{l}2383(45 \%) \\
2934(55 \%)\end{array}$ \\
\hline $\begin{array}{l}\text { Social media application } \\
\text { Twitter } \\
\text { Snapchat } \\
\text { Instagram } \\
\text { Other }\end{array}$ & $\begin{array}{l}N=2374 \\
1266(37 \%) \\
734(22 \%) \\
1045(31 \%) \\
336(10 \%)\end{array}$ \\
\hline $\begin{array}{l}\text { Clinic color } \\
\text { Yellow } \\
\text { Black } \\
\text { White } \\
\text { Green } \\
\text { Blue }\end{array}$ & $\begin{array}{l}248(5 \%) \\
273(5 \%) \\
2966(56 \%) \\
232(4 \%) \\
1598(30 \%)\end{array}$ \\
\hline
\end{tabular}


Table 3 Descriptive Analysis on the Importance of the Variables Studied

\begin{tabular}{|c|c|}
\hline Variable & $\mathbf{N}(\%)$ \\
\hline $\begin{array}{l}\text { Importance of dentist nationality } \\
\text { Very important } \\
\text { Important } \\
\text { Not important }\end{array}$ & $\begin{array}{l}942(18 \%) \\
1197(23 \%) \\
3178(60 \%)\end{array}$ \\
\hline $\begin{array}{l}\text { Importance of dentist sex } \\
\text { Very important } \\
\text { Important } \\
\text { Not important }\end{array}$ & $\begin{array}{l}998(19 \%) \\
1530(29 \%) \\
2789(52 \%)\end{array}$ \\
\hline $\begin{array}{l}\text { Importance of dentist age } \\
\text { Very important } \\
\text { Important } \\
\text { Not important }\end{array}$ & $\begin{array}{l}587(11 \%) \\
1534(29 \%) \\
3196(60 \%)\end{array}$ \\
\hline $\begin{array}{l}\text { Importance of dentist rank } \\
\text { Very important } \\
\text { Important } \\
\text { Not important }\end{array}$ & $\begin{array}{l}2753(52 \%) \\
1875(35 \%) \\
689(13 \%)\end{array}$ \\
\hline $\begin{array}{l}\text { Importance of dentist reputation } \\
\text { Very important } \\
\text { Important } \\
\text { Not important }\end{array}$ & $\begin{array}{l}355 \mid(67 \%) \\
\mid 458(27 \%) \\
308(6 \%)\end{array}$ \\
\hline $\begin{array}{l}\text { Importance of dentist recommendation } \\
\text { Very important } \\
\text { Important } \\
\text { Not important }\end{array}$ & $\begin{array}{l}2620(49 \%) \\
1987(37 \%) \\
710(16 \%)\end{array}$ \\
\hline $\begin{array}{l}\text { Importance of dentist characteristics } \\
\text { Very important } \\
\text { Important } \\
\text { Not important }\end{array}$ & $\begin{array}{l}2486(47 \%) \\
2105(40 \%) \\
726(14 \%)\end{array}$ \\
\hline $\begin{array}{l}\text { Importance of dentist attire } \\
\text { Very important } \\
\text { Important } \\
\text { Not important }\end{array}$ & $\begin{array}{l}942(18 \%) \\
186 \mid(35 \%) \\
2514(47 \%)\end{array}$ \\
\hline $\begin{array}{l}\text { Importance of social media } \\
\text { Very important } \\
\text { Important } \\
\text { Not important }\end{array}$ & $\begin{array}{l}526(10 \%) \\
1232(23 \%) \\
3559(67 \%)\end{array}$ \\
\hline $\begin{array}{l}\text { Importance of cost } \\
\text { Very important } \\
\text { Important } \\
\text { Not important }\end{array}$ & $\begin{array}{l}3254(61 \%) \\
1737(33 \%) \\
326(6 \%)\end{array}$ \\
\hline $\begin{array}{l}\text { Importance of location } \\
\text { Very important } \\
\text { Important } \\
\text { Not important }\end{array}$ & $\begin{array}{l}2322(44 \%) \\
2081(39 \%) \\
914(17 \%)\end{array}$ \\
\hline
\end{tabular}

(Continued)
Table 3 (Continued).

\begin{tabular}{|l|l|}
\hline Variable & N (\%) \\
\hline Importance of clinic color & \\
Very important & $708(13 \%)$ \\
Important & $1582(30 \%)$ \\
Not important & $3027(57 \%)$ \\
\hline
\end{tabular}

dentists to younger ones (6\%) (see Table 2). There was no effect of the demographic data on the preference of dentist age. Most of the participants $(60 \%)$ rated this variable as not important when choosing their dentists (see Table 3).

\section{Dentist Rank}

Approximately $38 \%$ of the participants preferred consultants, while $32 \%$ preferred specialists, $24 \%$ did not matter to them the dentist rank, and only 5\% preferred general dentists (see Table 2). There was no effect of the participants demographic data on the preference of dentist rank, except for the sex and age of the participants, which shows that majority of female participants $44 \%$ preferred consultants, while male participants $36 \%$ preferred specialists $(p<0.0001)$. Moreover, participants who aged 26 and above preferred consultants whereas participants younger than 25 years preferred specialists. Most of the participants $(52 \%)$ rated this variable as very important when choosing their dentists (see Table 3).

\section{Dentist Reputation}

About $83 \%$ of the participants preferred a well-known dentist, while $16 \%$ of the participants did not matter to them the dentist's reputation (see Table 2). Most of the participants $(67 \%)$ rated this variable as very important when choosing their dentists (see Table 3).

\section{Dentist Characteristics}

The majority of the participants (78\%) stated that they prefer dentists who are explanatory and $22 \%$ prefer dentists who are listeners (see Table 2). Most of the participants $(47 \%)$ rated this variable as very important when choosing their dentists (see Table 3).

\section{Male Dentists' Attire}

The majority of the participants (41\%) preferred male dentists in scrubs and lab coats, followed by $32 \%$ of scrubs only, while $26 \%$ preferred formal and lab coats, and only $1 \%$ preferred traditional Saudi clothes (see Figure 1). There was a significant difference between male and 
Table 4 Association Between the Preferred Dentist's Specialty and the Sex and Age of the Participants

\begin{tabular}{|c|c|c|c|c|c|c|c|}
\hline & & Variables & Male Dentist & Female Dentist & Does Not Matter & P value* & Total \\
\hline General Dentist & \multirow{3}{*}{ Age } & $\begin{array}{l}<21 \text { years old } \\
22-25 \text { years old } \\
26-31 \text { years old } \\
32-41 \text { years old } \\
>42 \text { years old }\end{array}$ & $\begin{array}{l}31.2 \% \\
31.3 \% \\
38.5 \% \\
39.1 \% \\
40.7 \%\end{array}$ & $\begin{array}{l}16.7 \% \\
20.3 \% \\
18.8 \% \\
22.3 \% \\
24.4 \%\end{array}$ & $\begin{array}{l}52.1 \% \\
48.4 \% \\
42.7 \% \\
38.7 \% \\
34.8 \%\end{array}$ & 0001 & \multirow{3}{*}{5317} \\
\hline Pedodontist & & $\begin{array}{l}<21 \text { years old } \\
22-25 \text { years old } \\
26-31 \text { years old } \\
32-41 \text { years old } \\
>42 \text { years old }\end{array}$ & $\begin{array}{l}16.7 \% \\
20.1 \% \\
24.3 \% \\
30.2 \% \\
29.7 \%\end{array}$ & $\begin{array}{l}36.2 \% \\
30.5 \% \\
32.8 \% \\
35.2 \% \\
35.7 \%\end{array}$ & $\begin{array}{l}47.1 \% \\
49.4 \% \\
43 \% \\
34.6 \% \\
34.5 \%\end{array}$ & 0001 & \\
\hline Oral and Maxillofacial Surgeon & & $\begin{array}{l}<21 \text { years old } \\
22-25 \text { years old } \\
26-31 \text { years old } \\
32-41 \text { years old } \\
>42 \text { years old }\end{array}$ & $\begin{array}{l}34.1 \% \\
39.2 \% \\
49.5 \% \\
56.7 \% \\
64 \%\end{array}$ & $\begin{array}{l}13.8 \% \\
13.1 \% \\
10.2 \% \\
12 \% \\
10.7 \%\end{array}$ & $\begin{array}{l}52.1 \% \\
47.7 \% \\
40.4 \% \\
31.4 \% \\
25.4 \%\end{array}$ & 0001 & \\
\hline
\end{tabular}

Note: $*$ Chi square test was used for categorical association.

female participants towards the preferred attire $(p<$ $0.0001)$, as $39 \%$ of male participants preferred scrubs only, while $49 \%$ of female participants preferred scrub and lab coats (see Table 5). Also, those who were younger than 31 years preferred scrub and lab coat, while older participants preferred scrubs only (see Table 5).

\section{Female Dentists' Attire}

Most of the participants (38\%) preferred female dentist attire in scrub and lab coat, $28 \%$ preferred black skirt and lab coat, followed by $26 \%$ preferred formal and lab coat, and only $8 \%$ preferred colored clothes and lab coat (see Figure 2). There was a significant difference between different age groups of the participants towards their preferred female attire $(p<0.0001)$ as $33 \%$ of participants who aged 42 years old or older preferred black skirt and lab coat, while younger participants preferred scrub and lab coat (see Table 6). Most of the participants (47\%) rated this variable as not important when choosing their dentists (see Table 3).
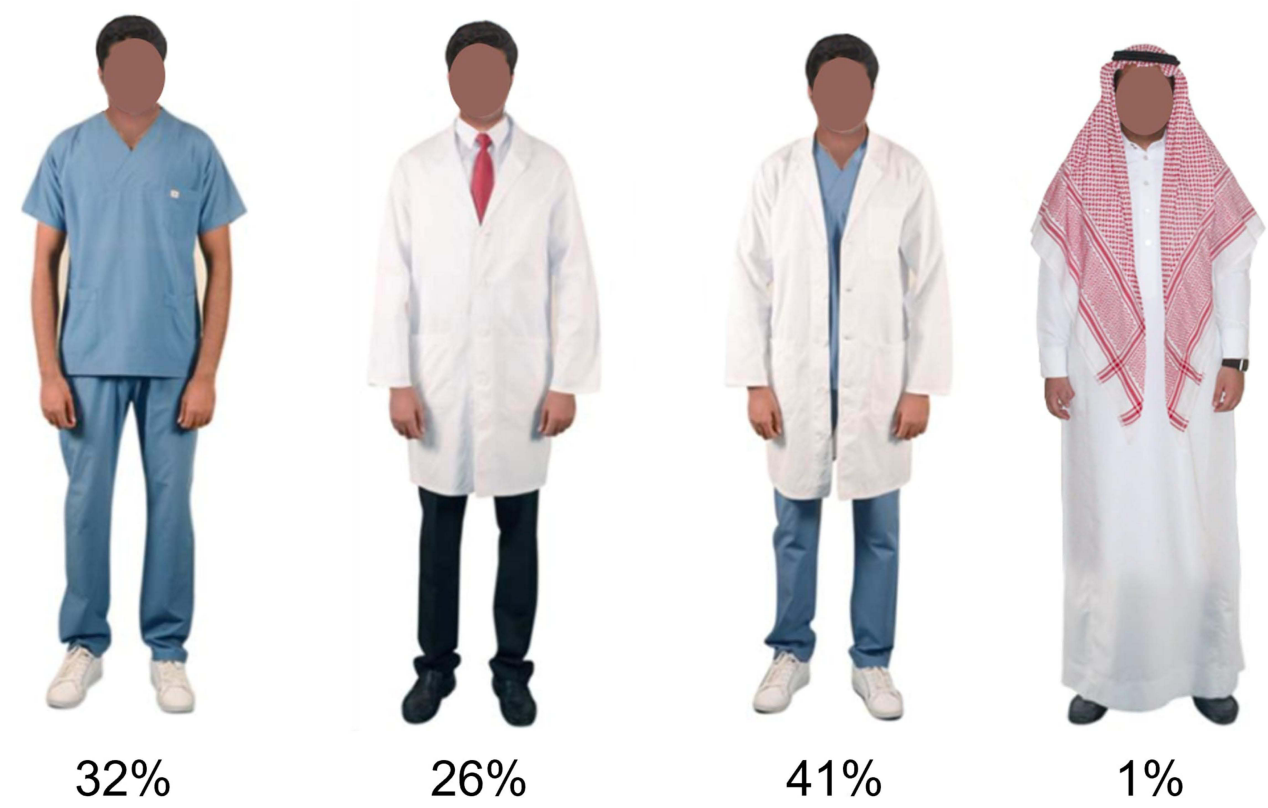

Figure I Participants' preferences on male dentist's attire. 
Table 5 Association Between the Preferred Male Attire and the Sex and Age of the Participants

\begin{tabular}{|c|c|c|c|c|c|c|c|}
\hline & & $\begin{array}{l}\text { Scrub } \\
\text { Only }\end{array}$ & $\begin{array}{l}\text { Formal and Lab } \\
\text { Coats }\end{array}$ & $\begin{array}{l}\text { Scrubs and Lab } \\
\text { Coats }\end{array}$ & $\begin{array}{l}\text { Traditional Saudi } \\
\text { Clothes }\end{array}$ & P value* & Total \\
\hline Sex & $\begin{array}{l}\text { Male } \\
\text { Female }\end{array}$ & $\begin{array}{l}38.5 \% \\
26.3 \%\end{array}$ & $\begin{array}{l}30 \% \\
23.3 \%\end{array}$ & $\begin{array}{l}29.5 \% \\
49.3 \%\end{array}$ & $\begin{array}{l}1.9 \% \\
1 \%\end{array}$ & 0001 & 5317 \\
\hline Age & $\begin{array}{l}<21 \text { years old } \\
22-25 \text { years old } \\
26-31 \text { years old } \\
32-41 \text { years old } \\
>42 \text { years old }\end{array}$ & $\begin{array}{l}25.6 \% \\
24.4 \% \\
35.5 \% \\
41.7 \% \\
35.4 \%\end{array}$ & $\begin{array}{l}25 \% \\
31 \% \\
24.8 \% \\
20.4 \% \\
28.5 \%\end{array}$ & $\begin{array}{l}47.7 \% \\
43.5 \% \\
38.7 \% \\
36.4 \% \\
33.4 \%\end{array}$ & \begin{tabular}{l|}
$1.4 \%$ \\
$1 \%$ \\
$0.8 \%$ \\
$1.3 \%$ \\
$2.3 \%$
\end{tabular} & 0001 & 5315 \\
\hline
\end{tabular}

Note: *Chi square test was used for categorical association.

\section{Dentist Social Media Accounts}

The majority of the participants $(55 \%)$ did not matter to them if their dentist has a social media account, while $45 \%$ preferred their dentist to have a social media account (see Table 2). It was found that significantly more male participants did not matter to them dentist's presence on social media $(63 \%)$, while $50 \%$ of females preferred dentist with social media account $(p<0.0001)$ (see Table 7). In case the dentist has a social media account, twitter was the most preferred platform (37\%), followed by Instagram (31\%) (see Table 2). Most of the participants $(67 \%)$ rated this variable as not important when choosing their dentists (see Table 3).

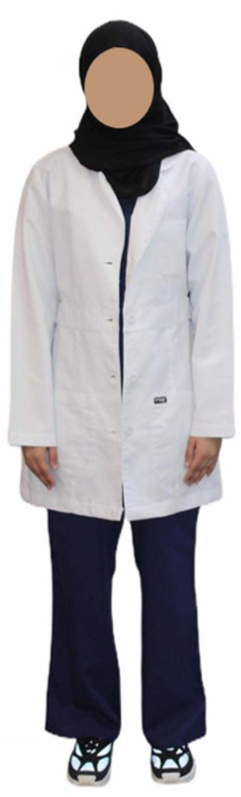

$38 \%$
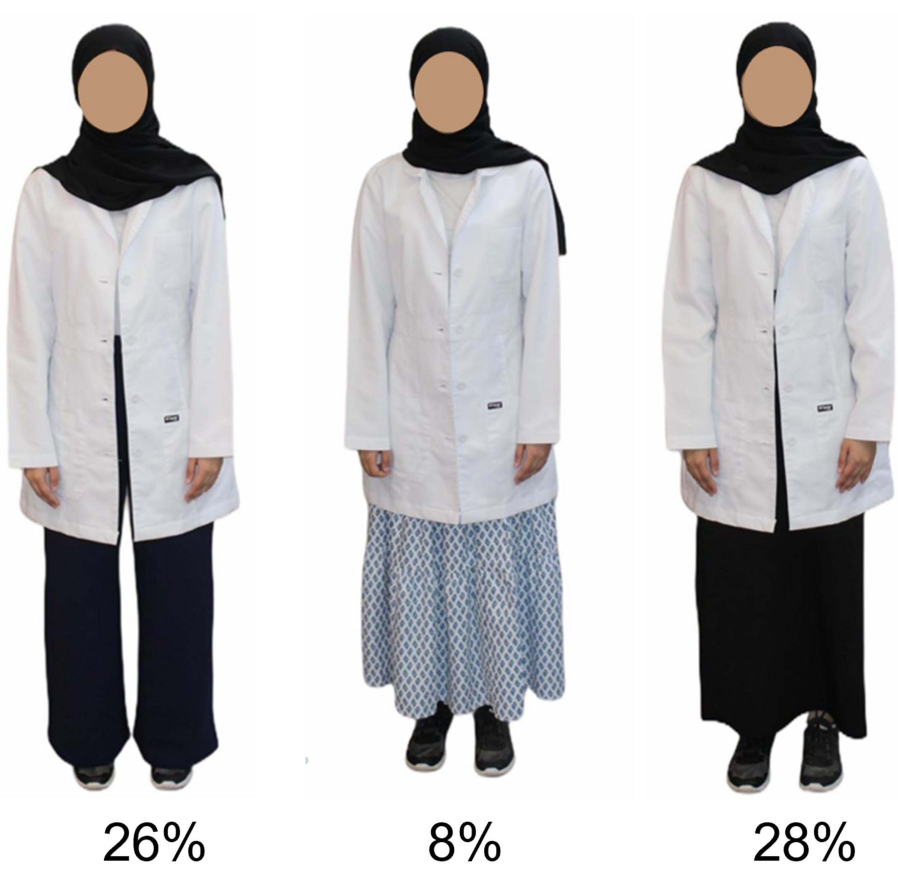

Figure 2 Participants' preferences on female dentist's attire.

\section{Clinic Color}

White clinic color was the most preferred among the participants by $56 \%$, followed by $30 \%$ blue color, $5 \%$ equal for both yellow and black colors, then $4 \%$ of green color (see Figure 3). There was no difference between the different demographic types toward the preferred clinic color. Most of the participants $(57 \%)$ rated this variable as not important when choosing their dentists (see Table 3).

Among the tested variables, the majority of the participants rated that recommendation on dentists, treatment cost and clinic location as very important to them when choosing their dentist (see Table 3 ). 
Table 6 Association Between the Preferred Female Attire and the Age of the Participants

\begin{tabular}{|c|c|c|c|c|c|c|c|}
\hline & & $\begin{array}{l}\text { Scrub and } \\
\text { Lab Coat }\end{array}$ & $\begin{array}{l}\text { Formal and } \\
\text { Lab Coat }\end{array}$ & $\begin{array}{l}\text { Colored Clothes and } \\
\text { Lab Coat }\end{array}$ & $\begin{array}{l}\text { Black Skirt and } \\
\text { Lab Coat }\end{array}$ & P value* & Total \\
\hline Age & $\begin{array}{l}<21 \text { years old } \\
22-25 \text { years old } \\
26-31 \text { years old } \\
32-41 \text { years old } \\
>42 \text { years old }\end{array}$ & $\begin{array}{l}45.5 \% \\
42.4 \% \\
36.9 \% \\
36.9 \% \\
25.4 \%\end{array}$ & $\begin{array}{l}28.8 \% \\
32.7 \% \\
27.5 \% \\
19 \% \\
18.5 \%\end{array}$ & $\begin{array}{l}2.1 \% \\
2.8 \% \\
4.9 \% \\
10.3 \% \\
22.8 \%\end{array}$ & $\begin{array}{l}23.4 \% \\
21.9 \% \\
30.5 \% \\
33.7 \% \\
33 \%\end{array}$ & 0001 & 5111 \\
\hline
\end{tabular}

Note: *Chi square test was used for categorical association.

Table 7 Association Between the Preferred Dentist Social Media and the Sex of the Participants

\begin{tabular}{|l|l|l|l|l|l|}
\hline & & Prefer Social Media & Does Not Matter & P value* & Total \\
\hline Sex & Male & $36.8 \%$ & $63 \%$ & 0001 & 5317 \\
& Female & $50 \%$ & $49 \%$ & & \\
\hline
\end{tabular}

Note: *Chi square test was used for categorical association.

\section{Discussion}

This study is one of the first in Saudi Arabia to explore the preference of patients in the selection of their dentists with respect to demographic data of participants. It was conducted on all five regions of Saudi Arabia, and surveyed 5317 participants from different ages, genders, and income levels, aiming to investigate what drives the preference of the Saudi population on their dentists. We found that dentists' nationality and social media interaction are not priority for participants when choosing their dentists. The preferred gender of the dentist differed between different specialties as male OMFS were preferred over female
OMFS, while female PDs were preferred over male PDs. We also found that dentists-interaction style, whether explanatory or listener, plays an important role and matters to the patients.

When a patient decides on their treating dentist, they consider different factors such as clinical rank, educational level, years of experience, recommendation from friends or family members and treatment cost. ${ }^{11}$ Some of these factors are within the capabilities of a dentist to work on to improve their patients' experience. Understanding these factors is key to the success of dental practices, especially from a business point of view. For instance, clinic location,

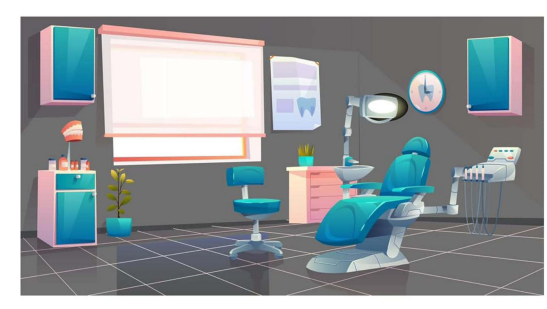

$5 \%$

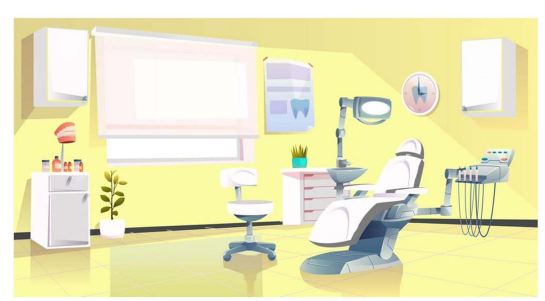

$5 \%$

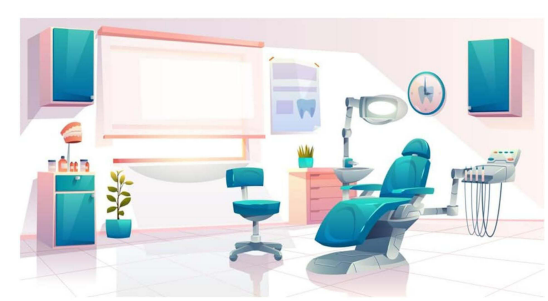

$56 \%$

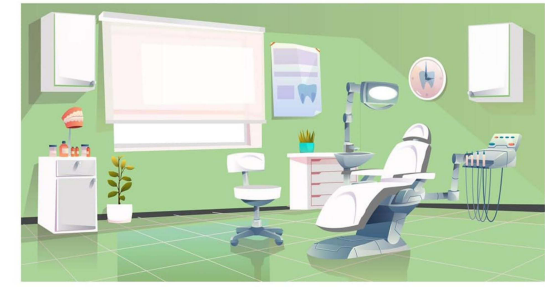

$4 \%$

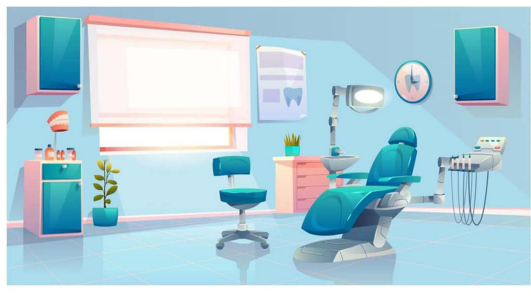

$30 \%$

Figure 3 Participants' preferences on different clinic colors. 
treatment cost and dentist reputation were found to be very important in our study compared to factors such as presence on social media or the color of the clinic. These results can help dentists to target the areas that matter to patients and hence can improve their financial outcomes.

A previous study conducted in 2014 in Riyadh, Saudi Arabia, investigated the preferences of Saudi population toward the male physician attire. The participants were provided with four pictures of male attire including western dress (shirt, necktie and white coat), surgical scrubs with white coat, surgical scrubs only and the Saudi national dress (thub and shmaq). About 40\% preferred western dress, while $33.3 \%$ preferred scrubs with a white coat. $^{12}$ In contrast, the results in this study showed more preferences toward the scrubs with white coat $41 \%$ followed by $32 \%$ for the scrubs only and only $26 \%$ for the western dress. Moreover, the previous study showed that the attire of the physician was very important for the participants, ${ }^{12}$ while in this study, $47.3 \%$ of male and $47.2 \%$ of female participants did not matter to them the dentist attire, which could reflect the attire is more important for physicians than dentists for Saudi participants.

Recently, many social media platforms were developed, with increasing acceptance by the population. Introducing these social media platforms to market dental services could be beneficial to dental practices. A previous study conducted in Jeddah, Saudi Arabia on a smaller sample (400 participants) found that Snapchat, followed by Instagram, were among the preferred platforms, especially for female patients. ${ }^{13}$ In contrast, our study found that Twitter was preferable to other platforms. This could be due to the fact that most of the participants in the previous study were younger than 25 years old and tended to use Snapchat more than other platforms. However, both studies concluded that the presence of dentists on social media is not as important as other factors. ${ }^{13}$

The way dentists communicate with patients during consultation visits plays an important role in the acceptance of patients to their dentists. Almost $90 \%$ of the participants in our study rated the personality of the dentists as important to very important when choosing a dentist. A previous study conducted in Jeddah, Saudi Arabia, identified professionalism by four domains according to the patient's perception, of which was practitioners' communication skills. ${ }^{11}$ Contributing to that, in the present study, the majority of Saudi prefer explanatory dentists to listeners.

There are few limitations to this study. This research was a cross-sectional study, and such studies are of a low evidence strength. An online survey was used in this study, which could result in a misunderstanding of some questions. We lack information regarding participants who do not respond to this survey and probably have different preferences towards dentist.

\section{Conclusions}

Considering the limitations of the study, we concluded that:

1. The dentist's reputation, rank and recommendation are the most important factors for patients selecting their dentist.

2. Social media accounts, dentist age and nationality are the least important factors for patients when selecting a dentist.

3. Most participants preferred dentists who spent more time explaining procedures to their patients.

4. Avoiding dark colors could be considered when designing dental clinics.

5. Wearing scrubs and lab coats and avoiding traditional Saudi clothes might be considered when dental practices plan their attire protocol.

6. The majority of participants preferred specialists and consultants. Hence, further education and postgraduate certificates can benefit dentists in their dental practices.

7. These factors can be considered during the establishment of clinical protocol.

\section{Disclosure}

The authors report no conflicts of interest in this work.

\section{References}

1. Tversky A, Simonson I. Context-dependent preferences. Manage Sci. 1993;39(10):1179-1189. doi:10.1287/mnsc.39.10.1179

2. Furnham A, Swami V. Patient preferences for dentists. Psychol Health Med. 2009;14(2):143-149. doi:10.1080/13548500802282690

3. Huraib SB, Al Nahas N, Al-Balbeesi HO, Abu-Aljadayl FM, Vellappally S, Sukumaran A. Patient preferences in selecting a dentist: survey results from the urban population of Riyadh, Saudi Arabia. J Contemp Dent Pract. 2015;16(3):201-204. doi:10.5005/jpjournals-10024-1661

4. Mercer E, MacKay-Lyons M, Conway N, Flynn J, Mercer C. Perceptions of outpatients regarding the attire of physiotherapists. PhysiotherCan. 2008;60(4):349-357.

5. Mckenna G, Lillywhite GR, Maini N. Patient preferences for dental clinical attire: a cross-sectional survey in a dental hospital. Br Dent $J$. 2007;203(12):681. doi:10.1038/bdj.2007.1109

6. Kazory A. Physicians, their appearance, and the white coat. Am J Med. 2018;121(9):825-828. doi:10.1016/j.amjmed.2008.05.030 
7. Alnasser Y, AlSaeed H, Al-Beeshi NZ, et al. Perception of pediatric physicians' attire by children and parents within general pediatrics practice in Saudi Arabia. J Health Educ Res Dev. 2015;4(4):199.

8. Souza-Constantino AM, Cláudia de Castro Ferreira Conti A, Capelloza Filho L, Marta SN, Rodrigues de Almeida-pedrin R. Patients' preferences regarding age, sex, and attire of orthodontists. Am J Orthod Dentofacial Orthop. 2018;154(6):829-834. doi:10.1016/j.ajodo.2018.02.013

9. Wayne W, Cross CL. Biostatistics: A Foundation of Analysis in the Health Science. 6th ed. John Wiley\&Sons; 1995.

10. Ngamjarus C, Chongsuvivatwong V.n4Studies: Sample Size and Power Calculation for IOS. The Royal Golden Jubilee Ph.D. Program - The Thailand Research Fund\&Prince of Songkla Univeristy; 2014.
11. Taibah S. Dental professionalism and influencing factors: patients' perception. Patient Prefer Adherence. 2018;12:1649-1658. doi:10.21 47/PPA.S172788

12. Batais M. Patients' attitudes toward the attire of male physicians: a single-center study in Saudi Arabia. Ann Saudi Med. 2014;34 (5):383-389.

13. Alalawi A, Aljuaid H, Natto ZS. The effect of social media on the choice of dental patients: a cross-sectional study in the city of Jeddah, Saudi Arabia. Patient Prefer Adherence. 2019;13:1685-1692. doi:10.2147/PPA.S213704
Patient Preference and Adherence

\section{Publish your work in this journal}

Patient Preference and Adherence is an international, peer-reviewed, open access journal that focusing on the growing importance of patient preference and adherence throughout the therapeutic continuum. Patient satisfaction, acceptability, quality of life, compliance, persistence and their role in developing new therapeutic modalities and compounds to optimize clinical outcomes for existing disease
Dovepress

states are major areas of interest for the journal. This journal has been accepted for indexing on PubMed Central. The manuscript management system is completely online and includes a very quick and fair peer-review system, which is all easy to use. Visit http:// www.dovepress.com/testimonials.php to read real quotes from published authors. 